\title{
Intronic polymorphisms of cytochromes P450
}

\begin{abstract}
Magnus Ingelman-Sundberg* and Sarah C. Sim
Section of Pharmacogenetics, Department of Physiology and Pharmacology, Karolinska Institutet, SE-171 77 Stockholm, Sweden *Correspondence to: Tel: +46 8524877 35; Fax: +46 83373 27; E-mail: magnus.ingelman-sundberg@ki.se
\end{abstract}

Date received (in revised form): 25th May 2010

\begin{abstract}
The cytochrome P450 enzymes active in drug metabolism are highly polymorphic. Most allelic variants have been described for enzymes encoded by the cytochrome P450 family 2 (CYP2) gene family, which has 252 different alleles. The intronic polymorphisms in the cytochrome P450 genes account for only a small number of the important variant alleles; however, the most important ones are CYP2D6*4 and CYP2D6*4I, which cause abolished and reduced CYP2D 6 activity, respectively, and CYP3A5*3 and CYP3A5*5, common in Caucasian populations, which cause almost null activity. Their discoveries have been based on phenotypic alterations within individuals in a population, and their identification has, in several cases, been difficult and taken a long time. In light of the nextgeneration sequencing projects, it is anticipated that further alleles with intronic mutations will be identified that can explain the hitherto unidentified genetic basis of inter-individual differences in cytochrome P450-mediated drug and steroid metabolism.
\end{abstract}

Keywords: pharmacogenetics, splicing defects, drug response, drug metabolism, POR

\section{Introduction}

The cytochrome P450 (CYP) enzymes are active in the metabolism of xenobiotics, as well as of endogenous compounds. In the human genome, 57 genes coding for active CYP enzymes and 58 pseudogenes have been identified. The CYP enzymes can be divided into two major classes: those that are active in the metabolism of exogenous chemicals, preferentially members of families $1-3$, and those that are mainly active in the metabolism of endogenous compounds, in particular steroids, fatty acids, cholesterol and cholesterol derivatives. Many of the active genes are highly polymorphic, as summarised on the Human Cytochrome P450 Allele Nomenclature (CYP-allele) website (http://www.cypalleles.ki.se/), and several hundred different variants have been identified. The most polymorphic gene among CYPs important for the metabolism of exogenous compounds is the CYP2D6 gene, for which about 80 different allelic variants have been described.
Other genes that are highly polymorphic in this gene family are CYP2C9 and CYP2C19, while other genes with important functional polymorphisms are CYP1A2, CYP1B1, CYP2A6, CYP2A13, CYP2B6, CYP2C8, CYP2J2, CYP2R1, CYP2W1, CYP3A4, CYP3A5, CYP3A7, CYP4A22, CYP4B1, CYP4F2, CYP5A1, CYP8A1, CYP19A1, CYP21A2 and $C Y P 26 A 1$. The highest number of variant alleles among the cytochromes $\mathrm{P} 450$ is seen in CYP21A2, which encodes the steroid 21 hydroxylase, for which 119 rare variants have been identified. In addition to the CYPs, NADPH cytochrome P450 reductase (POR), the electron donor for CYP enzymes, has been shown to have important polymorphic variants (http://www.cypalleles.ki.se/por.htm) and, recently, the second electron donor, cytochrome $b_{5}$, has also been shown to exhibit functional polymorphisms, ${ }^{1}$ although functionally variant alleles are rare.

In the field of pharmacogenetics, emphasis is put on the functionally important polymorphic CYP 
variants. This includes about 400 different alleles with non-synonymous mutations or important functional mutations; 79, 253, 34 and 25 variants are present in gene families CYP1, CYP2, CYP3 and CYP4, respectively (www.cypalleles.ki.se). The majority of the mutations of functional importance cause stop codons, non-synonymous mutations and splice defects. The variant alleles have, to a large extent, been identified based on an altered in vivo phenotype within a specific individual. In addition, targeted sequence screening projects have been carried out to search for non-synonymous mutations that have been expressed in heterologous systems and characterised functionally. The CYP alleles known so far have generally not been identified through large genomic sequencing projects. Results from such studies are expected to be published in the near future and to yield a high number of novel polymorphic loci. In the authors' laboratory, for example, the Korean genome has been aligned with the Caucasian genome for identification of mutations in the CYP2C locus. It is evident that thousands of mutations are localised in introns and gene-flanking regions which are not present in the current databases (Frank Nylén, unpublished observations).

\section{Intronic polymorphisms}

Among the P450 genes, only 15 different alleles with intronic mutations causing functional alterations have been identified so far (see Table 1). The majority are the result of sequencing efforts using genomic DNA from individuals shown to have altered CYP activity in vivo. Among these mutations, all but three abolish enzyme activity due to erroneous splicing.

Among the mutations listed in Table 1, several occur in the CYP21A2 gene, are rare and have been found because of loss of gene function causing congenital adrenal hyperplasia; however, intronic polymorphisms only account for 5 per cent of all functionally important mutations in this gene.

Intron mutations in the P450 genes encoding drug metabolising enzymes have been found in the
CYP1A2, CYP2D6, CYP2C19 and CYP3A5 genes. The $C Y P 1 A 2^{*} 7$ allele, which has a mutation disrupting the splice donor site in intron 6 , has only been identified in one single individual and not been considered in the literature after the initial identification. ${ }^{2}$ The same is also true for CYP2C19*7, which contains a single $\mathrm{T}>\mathrm{A}$ nucleotide transversion in the invariant GT at the $5^{\prime}$ donor splice site of intron 5, causing no functional protein to be expressed. By contrast, the intron mutations in the CYP2D6 and CYP3A5 genes are much more important.

\section{CYP2D6}

The CYP2D $6^{*} 4$ allele was the first defective CYP2D6 variant allele to be identified (in 1990), and constitutes the main explanation for the poor metaboliser (PM) phenotype among Caucasians. The $1846 \mathrm{G}>\mathrm{A}$ mutation disrupts the splice acceptor site in intron 3. Many of the other mutations present in this allele are also present in the partially defective $C Y P 2 D 6^{*} 10$ allele. ${ }^{19}$ The CYP2D6*10 allele is the most common CYP2D6 variant in many Asian populations. ${ }^{20}$ It is likely that this intronic mutation was introduced into the CYP2D6*10 allele in the past 10,000 to 20,000 years.

The CYP2D $6 * 41$ allele carries a $2988 \mathrm{G}>\mathrm{A}$ mutation in intron 6 , creating an alternate splice donor site. The CYP2D $6^{*} 41$ allele has a very high sequence homology with $C Y P 2 D 6^{*} 2$, but early investigations regarding the functional properties of the $C Y P 2 D 6^{*} 2$ allele revealed heterogeneous activity. Much later on, Toscano and collaborators showed the functional properties of the CYP2D $6^{*} 41$ allele giving rise to reduced enzyme activity expressed heterologously in COS-1 and Huh-7 cells. ${ }^{8}$ The extent of the decrease in activity caused by this allele is important, and carriers who are homozygous for CYP2D $6^{*} 41$ have a reduced activity similar in magnitude to those who are heterozygous for a defective CYP2D6 allele. $^{20}$ In addition to the CYP2D $6^{*} 41$ allele, Gaedigk et al. identified a similar rare variant, named CYP2D6*69, carrying an additional nonsynonymous mutation. ${ }^{6}$ 
Table I. Intronic polymorphism of the cytochrome P450 genes and of NADPH cytochrome P450 reductase (POR)

\begin{tabular}{|c|c|c|c|c|c|c|}
\hline Gene & Allele & $\begin{array}{l}\text { Genomic } \\
\text { position* }\end{array}$ & $\begin{array}{l}\text { Intronic } \\
\text { position }\end{array}$ & Effect & $\begin{array}{l}\text { Activity } \\
\text { in vivo }\end{array}$ & References \\
\hline CYPIA2 & CYPIA2*7 & $3533 G>A$ & IVS6 + IG > A & $\begin{array}{l}\text { Disruption of the splice donor } \\
\text { site in intron } 6\end{array}$ & None & 2 \\
\hline CYP2CI9 & CYP2CI9*7 & $19294 \mathrm{~T}>\mathrm{A}$ & $\mathrm{IVS} 5+2 \mathrm{~T}>\mathrm{A}$ & $\begin{array}{l}\text { Disruption of the splice donor } \\
\text { site in intron } 5\end{array}$ & None & 3 \\
\hline \multirow[t]{4}{*}{ CYP2D6 } & CYP2D6*4 & $1846 G>A$ & IVS3 - IG $>A$ & $\begin{array}{l}\text { Disruption of the splice } \\
\text { acceptor site in intron } 3\end{array}$ & None & 4 \\
\hline & CYP2D6*II & $883 G>C$ & $\mid V S I-I G>C$ & $\begin{array}{l}\text { Disruption of the splice } \\
\text { acceptor site in intron I }\end{array}$ & None & 5 \\
\hline & $\begin{array}{l}\text { CYP2D6*4I, } \\
\text { CYP2D6*69 }\end{array}$ & $2988 \mathrm{G}>\mathrm{A}$ & IVS6 $+39 \mathrm{G}>\mathrm{A}$ & $\begin{array}{l}\text { Insertion of an alternative splice } \\
\text { donor site in intron } 6\end{array}$ & Decreased & $6-8$ \\
\hline & CYP2D6*44 & $2950 G>C$ & IVS6 + IG >C & $\begin{array}{l}\text { Disruption of the splice donor } \\
\text { site in intron } 6\end{array}$ & None & 9 \\
\hline \multirow[t]{2}{*}{ СYРЗА5 } & СYР 3 A5*3 & $6986 A>G$ & IVS3 - 237A > G & $\begin{array}{l}\text { Insertion of an alternative splice } \\
\text { acceptor site in intron } 3\end{array}$ & Decreased & 10 \\
\hline & СYР 3 A5*5 & $12952 T>C$ & IVS5 $+2 \mathrm{~T}>\mathrm{C}$ & $\begin{array}{l}\text { Disruption of the splice donor } \\
\text { site in intron } 5\end{array}$ & None & II \\
\hline \multirow[t]{6}{*}{ CYP2 IA2 } & $\begin{array}{l}\text { Common } 12 \\
\text { splice } \\
\text { variant** }\end{array}$ & $655 \mathrm{~A} / \mathrm{C}>\mathrm{G}$ & $\begin{array}{l}\text { IVS2 - I3A/ } \\
C>G\end{array}$ & $\begin{array}{l}\text { Insertion of an alternative splice } \\
\text { acceptor site in intron } 2\end{array}$ & Decreased & 12 \\
\hline & CYP2 IA2*26 & $1779 G>C$ & IVS7 + IG >C & $\begin{array}{l}\text { Disruption of the splice donor } \\
\text { site in intron } 7\end{array}$ & None & 13 \\
\hline & CYP2IA2*3I & $295 A>G$ & $\mid \mathrm{VSI} I-2 \mathrm{~A}>\mathrm{G}$ & $\begin{array}{l}\text { Disruption of the splice } \\
\text { acceptor site in intron I }\end{array}$ & None & 14 \\
\hline & CYP2 IA2*39 & $387 G>A$ & $\mathrm{IVS} 2+\mathrm{IG}>\mathrm{A}$ & $\begin{array}{l}\text { Disruption of the splice donor } \\
\text { site in intron } 2\end{array}$ & None & 15 \\
\hline & CYP2IA2*43 & $1780 \mathrm{~T}>\mathrm{G}$ & $\mathrm{IVS7}+2 \mathrm{~T}>\mathrm{G}$ & $\begin{array}{l}\text { Disruption of the splice donor } \\
\text { site in intron } 7\end{array}$ & None & 16 \\
\hline & CYP2 IA2*68 & $666 \mathrm{~A}>\mathrm{G}$ & IVS2 $-2 A>G$ & $\begin{array}{l}\text { Disruption of the splice } \\
\text { acceptor site in intron } 2\end{array}$ & None & 17 \\
\hline POR & $P O R * 3$ & $27615 G>A$ & IVS6 + IG > A & $\begin{array}{l}\text { Disruption of the splice donor } \\
\text { site in intron } 6\end{array}$ & Decreased & 18 \\
\hline
\end{tabular}

* A in translational start codon ATG is denoted $+\mathrm{I}$.

** The 12 splice variant is found in several different alleles.

\section{CYP3A5}

The metabolism of clinically important drugs is primarily carried out by the CYP3A4 and CYP3A5 enzymes. They have very similar substrate specificities, with CYP3A5 being less efficient. ${ }^{20}$ The CYP3A4 gene is very well conserved, and no common functionally important variant allele has been identified. This is not the case regarding the CYP3A5 gene. Based on phenotype differences between individuals, Kuehl and collaborators sequenced the CYP3A5 gene and identified the variant allele $C Y P 3 A 5^{*} 3$ with a $6986 \mathrm{~A}>\mathrm{G}$ 
mutation creating an alternate splice acceptor site in intron $3 .^{10}$ Prior to identifying the real background for the defective CYP3A5 allele, several mutations in the $5^{\prime}$-region were thought to form the genetic basis for the reduced CYP3A5 expression. Also the CYP3A5*5 allele with a $12952 \mathrm{~T}>\mathrm{C}$ mutation that results in a disruption of the splice donor site in intron 5 was found in the Chinese. ${ }^{11}$ Interestingly, the $C Y P 3 A 5^{*} 3$ and $C Y P 3 A 5^{*} 5$ alleles are much less common in African populations, causing an overall higher capability for CYP3A-dependent hydroxylase activities. Since CYP3A5 is also expressed in the foetal liver, this polymorphism additionally creates a higher detoxifying potential in foetuses of African origin. ${ }^{21}$

In conclusion, the intronic polymorphisms in the CYP genes account for only a small number of the important variant alleles. Their discoveries have been based on phenotypic alterations within individuals in a population, and their identification has, in several cases, been difficult and taken a long time. As a result of the next-generation sequencing projects, it is anticipated that new, important information regarding the intron sequence variability among the CYP genes will be discovered, and that further alleles will be identified that can explain the hitherto unidentified genetic basis of inter-individual differences in CYP-mediated drug and steroid metabolism.

\section{Acknowledgments}

The research in the authors laboratory is supported by grants from the Swedish Research Council, The Swedish Cancer Fund and by Vinnova.

\section{References}

1. Sacco, J.C. and Trepanier, L.A. (2010), 'Cytochrome b5 and NADH cytochrome b5 reductase: Genotype-phenotype correlations for hydroxylamine reduction', Pharmacogenet. Genomics Vol. 20, pp. 26-37.

2. Allorge, D., Chevalier, D., Lo-Guidice, J.M., Cauffiez, C. et al. (2003), 'Identification of a novel splice-site mutation in the CYP1A2 gene', Br. J. Clin. Pharmacol. Vol. 56, pp. 341-344.

3. Ibeanu, G.C., Blaisdell, J., Ferguson, R.J., Ghanayem, B.I. et al. (1999), 'A novel transversion in the intron 5 donor splice junction of CYP2C19 and a sequence polymorphism in exon 3 contribute to the poor metabolizer phenotype for the anticonvulsant drug S-mephenytoin', J. Pharmacol. Exp. Ther. Vol. 290, pp. 635-640.

4. Kagimoto, M., Heim, M., Kagimoto, K., Zeugin, T. et al. (1990), 'Multiple mutations of the human cytochrome P450IID6 gene
(CYP2D6) in poor metabolizers of debrisoquine. Study of the functional significance of individual mutations by expression of chimeric genes', J. Biol. Chem. Vol. 265, pp. 17209-17214.

5. Marez, D., Sabbagh, N., Legrand, M., Lo-Guidice, J.M. et al. (1995), 'A novel CYP2D6 allele with an abolished splice recognition site associated with the poor metabolizer phenotype', Pharmacogenetics Vol. 5, pp. 305311.

6. Gaedigk, A., Frank, D. and Fuhr, U. (2009), 'Identification of a novel non-functional CYP2D6 allele, CYP2D6*69, in a Caucasian poor metabolizer individual', Eur. J. Clin. Pharmacol. Vol. 65, pp. 97-100.

7. Rau, T., Diepenbruck, S., Diepenbruck, I. and Eschenwagen, T. (2006), 'The 2988G $>$ A polymorphism affects splicing of a CYP2D6 minigene', Clin. Pharmacol. Ther. Vol. 80, pp. 555-558.

8. Toscano, C., Klein, K., Blievernicht, J., Schaeffeler, E. et al. (2006), 'Impaired expression of CYP2D6 in intermediate metabolizers carrying the *41 allele caused by the intronic SNP 2988G $>$ A: Evidence for modulation of splicing events', Pharmacogenet. Genomics Vol. 16, pp. 755-766.

9. Yamazaki, H., Kiyotani, K., Tsubuko, S., Matsunaga, M. et al. (2003), 'Two novel haplotypes of CYP2D6 gene in a Japanese population', Drug Metab. Pharmacokinet. Vol. 18, pp. 269-271.

10. Kuehl, P., Zhang, J., Lin, Y., Lamba, J. et al. (2001), 'Sequence diversity in CYP3A promoters and characterization of the genetic basis of polymorphic CYP3A5 expression', Nat. Genet. Vol. 27, pp. 383-391.

11. Chou, F.C., Tzeng, S.J. and Huang, J.D. (2001), 'Genetic polymorphism of cytochrome P450 3 A5 in Chinese', Drug Metab. Dispos. Vol. 29, pp. 1205-1209.

12. Rodrigues, N.R., Dunham, I., Yu, C.Y., Carroll, M.C. et al. (1987), 'Molecular characterization of the HLA-linked steroid 21-hydroxylase B gene from an individual with congenital adrenal hyperplasia', EMBO J. Vol. 6, pp. 1653-1661.

13. Wedell, A. and Luthman, H. (1993), 'Steroid 21-hydroxylase deficiency: Two additional mutations in salt-wasting disease and rapid screening of disease-causing mutations', Hum. Mol. Genet. Vol. 2, pp. 499-504.

14. Lajic, S. and Wedell, A. (1996), 'An intron 1 splice mutation and a nonsense mutation (W23X) in CYP21 causing severe congenital adrenal hyperplasia', Hum. Genet. Vol. 98, pp. 182-184.

15. Lee, H.H., Chao, H.T., Lee, Y.J., Shu, S.C. et al. (1998), 'Identification of four novel mutations in the CYP21 gene in congenital adrenal hyperplasia in the Chinese', Hum. Genet. Vol. 103, pp. 304-310.

16. Ordoñez-Sánchez, M.L., Ramírez-Jiménez, S., López-Gutierrez, A.U., Riba, L. et al. (1998), 'Molecular genetic analysis of patients carrying steroid 21-hydroxylase deficiency in the Mexican population: Identification of possible new mutations and high prevalence of apparent germ-line mutations', Hum. Genet. Vol. 102, pp. 170-177.

17. Billerbeck, A.E., Mendonca, B.B., Pinto, E.M., Madureira, G. et al. (2002), 'Three novel mutations in CYP21 gene in Brazilian patients with the classical form of 21-hydroxylase deficiency due to a founder effect', J. Clin. Endocrinol. Metab. Vol. 87, pp. 4314-4317.

18. Flück, C.E., Tajima, T., Pandey, A.V., Arlt, W. et al. (2004), 'Mutant P450 oxidoreductase causes disordered steroidogenesis with and without Antley-Bixler syndrome', Nat. Genet. Vol. 36, pp. 228-230.

19. Johansson, I., Oscarson, M., Yue, Q.Y., Bertilsson, L. et al. (1994), 'Genetic analysis of the Chinese cytochrome P4502D locus: Characterization of variant CYP2D6 genes present in subjects with diminished capacity for debrisoquine hydroxylation', Mol. Pharmacol. Vol. 46, pp. $452-459$.

20. Ingelman-Sundberg, M., Sim, S.C., Gomez, A. and Rodriguez-Antona, C. (2007), 'Influence of cytochrome P450 polymorphisms on drug therapies: Pharmacogenetic, pharmacoepigenetic and clinical aspects', Pharmacol. Ther. Vol. 116, pp. 496-526.

21. Rodríguez-Antona, C., Jande, M., Rane, A. and Ingelman-Sundberg, M. (2005), 'Identification and phenotype characterization of two CYP3A haplotypes causing different enzymatic capacity in fetal livers', Clin. Pharmacol. Ther. Vol. 77, pp. 259-270. 